\title{
Realization of daily evapotranspiration in arid ecosystems based on remote sensing techniques
}

\author{
Mohamed Elhag and Jarbou A. Bahrawi \\ Department of Hydrology and Water Resources Management, Faculty of Meteorology, Environment \& \\ Arid Land Agriculture, King Abdulaziz University Jeddah, 21589, Saudi Arabia \\ Correspondence to: Mohamed Elhag (melhag@kau.edu.sa)
}

Received: 28 November 2016 - Discussion started: 8 December 2016

Revised: 6 February 2017 - Accepted: 25 February 2017 - Published: 14 March 2017

\begin{abstract}
Daily evapotranspiration is a major component of water resources management plans. In arid ecosystems, the quest for an efficient water budget is always hard to achieve due to insufficient irrigational water and high evapotranspiration rates. Therefore, monitoring of daily evapotranspiration is a key practice for sustainable water resources management, especially in arid environments. Remote sensing techniques offered a great help to estimate the daily evapotranspiration on a regional scale. Existing open-source algorithms proved to estimate daily evapotranspiration comprehensively in arid environments. The only deficiency of these algorithms is the course scale of the used remote sensing data. Consequently, the adequate downscaling algorithm is a compulsory step to rationalize an effective water resources management plan. Daily evapotranspiration was estimated fairly well using an Advance Along-Track Scanner Radiometer (AATSR) in conjunction with (MEdium Resolution Imaging Spectrometer) MERIS data acquired in July 2013 with $1 \mathrm{~km}$ spatial resolution and 3 days of temporal resolution under a surface energy balance system (SEBS) model. Results were validated against reference evapotranspiration ground truth values using standardized Penman-Monteith method with $R^{2}$ of 0.879 . The findings of the current research successfully monitor turbulent heat fluxes values estimated from AATSR and MERIS data with a temporal resolution of 3 days only in conjunction with reliable meteorological data. Research verdicts are necessary inputs for a well-informed decisionmaking processes regarding sustainable water resource management.
\end{abstract}

\section{Introduction}

Evapotranspiration is the principle process in defining mass and energy relationship in the surrounding hydrosphere (Allen et al., 2007a, b; Cruz-Blanco et al., 2014). The consumptive use of irrigational water in agriculture is the fundamental component of a balanced estimation of evapotranspiration (Bastiaanssen et al., 2011; Cammalleri and Ciraolo, 2013).

The concept of water use efficacy basically depends on the reliable estimation of evapotranspiration and surface water evaporation (Berengena and Gavilán, 2005; Elhag et al., 2011). Weather and wind conditions induce a regional and seasonal variation of evapotranspiration estimation (Hanson, 1991; Cristóbal and Anderson, 2013).

Conventional techniques of field scale evapotranspiration estimations are achieved, especially over homogenous surfaces using ordinary techniques: lysimeter systems, eddy covariance (EC) and Bowen ratio (BR). Nevertheless, conventional methods of evapotranspiration estimations are incapable of fulfilling the quest for regional evapotranspiration estimation, specifically in harsh climatic conditions (Gavilán et al., 2006; Ghilain et al., 2011). Therefore, remote sensing evapotranspiration models are adequate techniques for obtaining satisfactory estimates (Allen et al., 2007a, b; De Bruin et al., 2010).

Remote sensing evapotranspiration models are numerous. Several algorithms are already in practice with different complexity levels to estimate evapotranspiration based on different climatic conditions and land use variability (Elhag et al., 2011; Espadafor et al., 2011; Cristóbal and Anderson, 2013).

Based on several scholarly works by Roerink et al. (2000), Su (2002), Crago and Crowley (2005), Chávez et al. (2005), 
Loheide and Gorelick (2005), Allen et al. (2007a, b), Ghilain et al. (2011), Psilovikos and Elhag (2013) on remote sensing evapotranspiration-based algorithms, there are principally two types of evapotranspiration estimation concepts on terrestrial surfaces.

The first concept is to use the surface reflectance in different visible (VIS), near-infrared (NIR) and even extended to thermal infrared (TIR) portions of the electromagnetic spectrum to rationalize the surface energy balance (SEB). The other concept it to use vegetation indices derived from canopy reflectance to conceptualize remotely sensed crop coefficient $\left(K_{\mathrm{cr}}\right)$.

Ground truth data collection exercised at less than $1 \mathrm{~m}$ canopy height, at which all related surfaces fluxes and atmospheric surface variables of the vegetation cover takes place in an arid environment (Beljaars and Holtslag, 1991; Zwart and Bastiaanssen, 2004). Based on Brutsaert (1991, 1999), Monin-Obukhov similarity (MOS) and bulk atmospheric boundary layer (ABL) functions were calculated. Brutsaert (1999) suggested sets of criteria to estimate MOS or ABL if scaled down appropriately for a given circumstances. Brutsaert criteria are valid only for unstable conditions.

Therefore, van den Hurk and Holtslag (1995) adjusted and validated Brutsaert criteria using atmospheric surface layer scaling according to Brutsaert (1982) to be used in stable conditions. Generic estimation of surface albedo for vegetated land covers is based on the red $(R)$ and NIR band reflectance (Brest and Goward, 1987) model.

The aim of the current study is to monitor turbulent heat fluxes in Wadi ad-Dawasir to estimate the daily evapotranspiration rate and relative evaporation ratio using Advance Along-Track Scanner Radiometer (AATSR) and MEdium Resolution Imaging Spectrometer (MERIS) sensors. The final step is to identify the regression coefficient between the estimated evapotranspiration's rates and the actual ground truth data.

\section{Materials and methods}

\subsection{Study area}

The study area, the town of Wadi ad-Dawasir, is located on the plateau of Najd at Lat $44^{\circ} 43^{\prime}$ and Lon $20^{\circ} 29^{\prime}$; about $300 \mathrm{~km}$ south of the capital city Riyadh (Fig. 1). This study area comprised of gravelly tableland disconnected by insignificant sandy oases and isolated mountain bundles. Across the Arabian Peninsula the tableland slopes toward the east from an elevation of $1360 \mathrm{~m}$ in the west to $750 \mathrm{~m}$ at its easternmost limit. Wadi ad-Dawasir and Wadi al-Rummah are the most important remaining riverbeds in the study area. Wadi ad-Dawasir and Najran regions are the major irrigation water abstraction from Al-Wajid aquifer. Agriculture in the Wadi ad-Dawasir area consists of technically highly de- veloped farm enterprises that operate modern pivot irrigation system. The size of the centre pivot ranges from 30 to 60 ha with farms managing hundreds of them with the corresponding number of wells. The main crop grown in winter is wheat and occasionally potatoes, tomatoes, or melons. All year fodder consists of alfalfa, which is cut up to 10 times a year for food. Typical summer crops for fodder are sorghum and Rhodes grass, which is perennial, but dormant in winter. The shallow alluvial aquifers could not sustain the high groundwater abstraction rates for a long time and groundwater level declined dramatically in most areas. The meteorological features of the area are speckled. Five elements of meteorology are constantly recorded through fixed weather stations located within the study area. Temperature varies from a minimum temperature of $6^{\circ} \mathrm{C}$ to maximum temperature of $43^{\circ} \mathrm{C}$. Relative humidity is mostly stable at $24 \%$. Solar radiation of average sunrise duration is generally $11 \mathrm{~h} \mathrm{day}^{-1}$. Average wind speed is closer to $13 \mathrm{~km} \mathrm{~h}^{-1}$ and may reach up to $46 \mathrm{~km} \mathrm{~h}^{-1}$ in thunderstorm incidents. Finally, mean annual rainfall is about $37.6 \mathrm{~mm}$ (Al-Zahrani and Baig, 2011).

\subsection{Methodological framework}

The current research work is based on assessing a regression correlation between estimated evapotranspiration data conducted from AATSR and MERIS sensors and its corresponding ground truth evapotranspiration data conducted through standardized Penman-Monteith. Therefore, accurate synchronization of remote sensing data bypassing and ground truth data collection was exercised.

\subsection{SEBS model fundamentals}

Remote sensing data were acquired from AATSR and MERIS sensors on the 8th of July 2013. The satellite data were georeferenced to WGS-84 datum, atmospherically corrected using the Simplified Model for Atmospheric Correction (SMAC) (Rahman and Dedieu, 1994). Several meteorological data were collected from a stationary station located within the designated study area (2004-2014, average meteorological data).

The surface energy balance system (SEBS) was initiated by Su (2002) based on further surface energy balance index improvements. SEBS dynamicity works for regional and local evapotranspiration (ET) estimation. Regional ET estimation uses Monin-Obukhov similarity (MOS), bulk atmospheric similarity and thermal roughness principles. On the other hand, local ET estimation uses only atmospheric surface layer (ASL) scaling fundamentals (Brutsaert, 1999; Su, 2001; Su et al., 2001). The boundary conditions (wet and dry) are essential components in ET estimation using the SEBS model. According to the water availability limitation, $H_{\text {dry }}$ is considered to be equal to the available energy $\mathrm{AE}$ if evaporation is assumed to be "zero". Following the Penman-Monteith parameterization (Monteith, 1965, 1981), 




Figure 1. Location of the study area (Elhag, 2016).

wet boundary condition $\left(H_{\text {wet }}\right)$ is calculated as follows:

$H_{\text {wet }}=\mathrm{AE}-\frac{\left(\frac{\rho_{\alpha} C_{p}}{r_{\mathrm{ah}}}\right)\left(e_{\mathrm{s}}-\frac{e}{7}\right)}{1+\frac{\Delta}{\gamma}}$,

where $e$ is the actual vapour pressure $\left(\mathrm{kP}_{\mathrm{a}}\right), e_{\mathrm{S}}$ is the saturation vapour pressure $\left(\mathrm{kP}_{\mathrm{a}}\right), c$ is the psychrometric constant $\left(\mathrm{kP}_{\mathrm{a}}{ }^{\circ} \mathrm{C}^{-1}\right), \gamma$ is the rate of change of saturation vapour pressure with temperature $\left(\mathrm{kP}_{\mathrm{a}}{ }^{\circ} \mathrm{C}^{-1}\right)$ and $r_{\mathrm{ah}}$ is the bulk surface external or aerodynamic resistance $\left(\mathrm{s} \mathrm{m}^{-1}\right)$.

Consequently, an evaporative fraction $(\Lambda)$ and relative evaporative fraction $\left(\Lambda_{\mathrm{r}}\right)$ are calculated per image pixel as follows:

$\Lambda=\frac{\lambda E}{R_{\mathrm{n}}-G}=\frac{\Lambda_{\mathrm{r}} \cdot \lambda E_{\mathrm{wet}}}{R_{\mathrm{n}}-G}$

$\Lambda_{\mathrm{r}}=1-\frac{H-H_{\mathrm{wet}}}{H_{\mathrm{dry}}-H_{\mathrm{wet}}}$.

Daily evaporation is estimated based on the estimation of the evaporative fraction only when the daily net energy $(G)$ and the net radiation $\left(R_{\mathrm{n}}\right)$ are available. Therefore, the amplitude variation of the diurnal energy cycle is sky clarity dependent.

$H=(1-\Lambda)\left(R_{\mathrm{n}}-G\right)$

$\mathrm{LE}=\Lambda\left(R_{\mathrm{n}}-G\right)$

$E_{\text {daily }}=\Lambda_{0}^{24} \cdot \int_{\text {daytime }} \cdot \frac{R_{\mathrm{n}}-G_{0}}{\lambda_{\rho \omega}}$,

where $\Lambda$ is the evaporative fraction, $\Lambda_{\mathrm{r}}$ is the relative evaporative fraction, $R_{\mathrm{n}}$ is net radiation measured in $\mathrm{W} \mathrm{m}^{-2}, G$ is soil heat flux measured in $\mathrm{W} \mathrm{m}^{-2}, H$ is turbulent sensible heat flux measured in $\mathrm{W} \mathrm{m}^{-2}, \lambda E$ is turbulent latent heat flux measured in $\mathrm{W} \mathrm{m}^{-2}, H$ is the actual sensible heat flux, determined by the bulk atmospheric similarity approach. $P \omega$ is the density of water measured in $\mathrm{kg} \mathrm{m}^{-3}$.

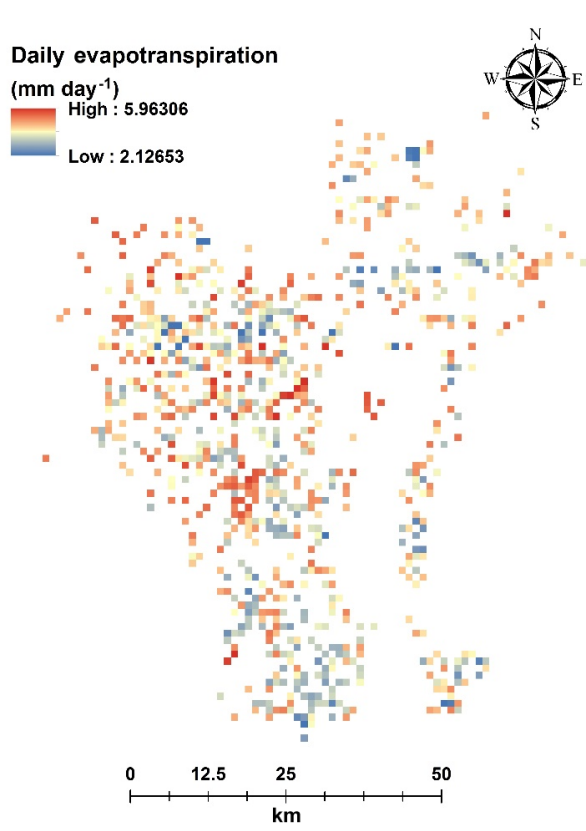

Figure 2. Actual daily evapotranspiration thematic map.

\subsection{Validation}

Using a standardized Penman-Monteith method, 50 ground truths data were collected and used to validate the implemented model. The sampling locations were consistently distributed over the designated study area. The lysimeter technique for the estimation of daily evapotranspiration was carried out following Liu and Wang (1999) with calibrated accuracy equal to \pm 0.025 . The calibration procedure was principally based on placing double infiltrometers (Taylor, 1981).

The corrected Penman equations for estimating the daily evapotranspiration was conducted according to Jensen et 


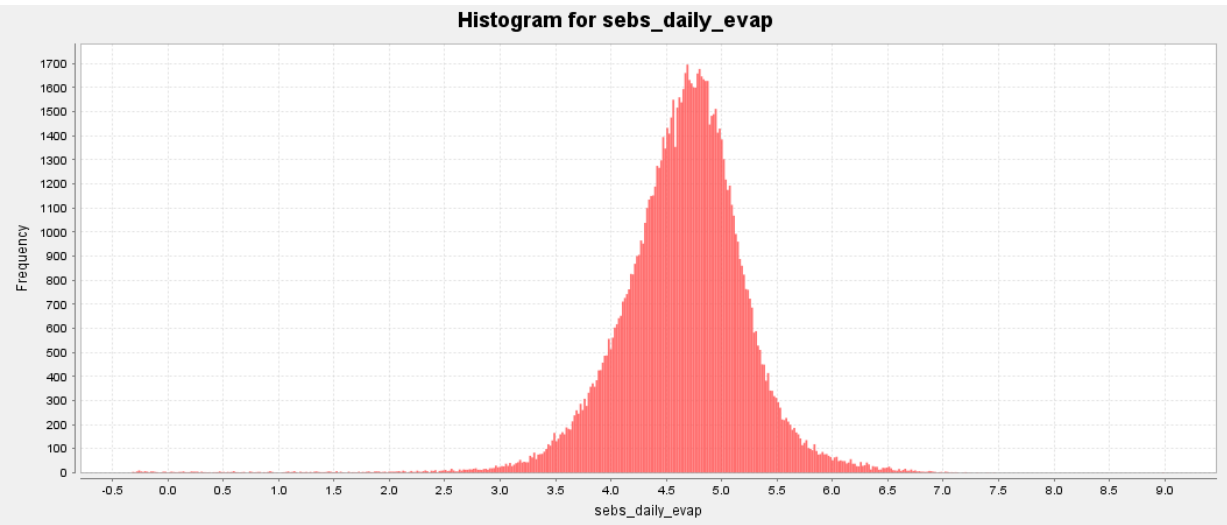

Figure 3. Normal distribution of actual daily evapotranspiration data.

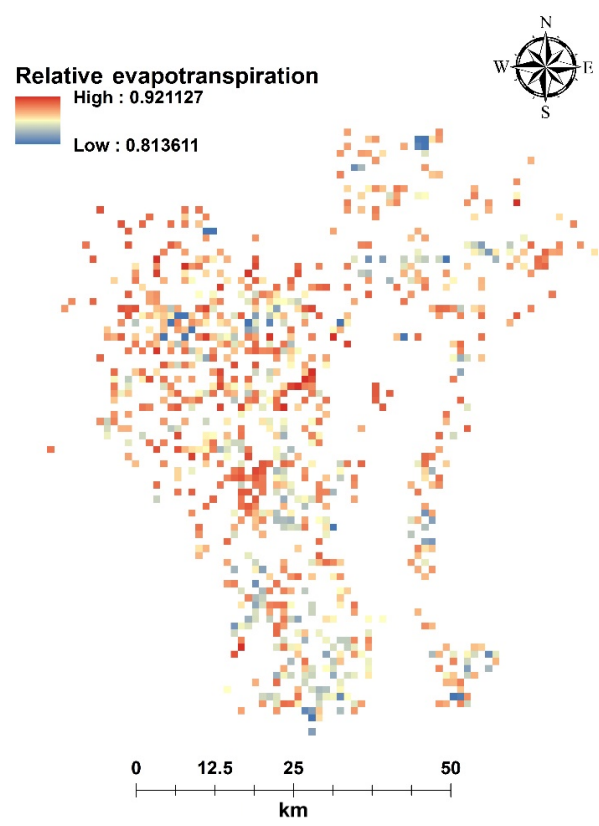

Figure 4. Relative evaporation thematic map.

al. (1995):

$\mathrm{ET}_{\mathrm{o}}=\left[\frac{\Delta}{\Delta+\gamma} R_{\mathrm{n}}+\frac{\gamma}{\Delta+\gamma} f(U)\left(e_{\mathrm{s}}-e_{\mathrm{a}}\right)\right] c$,

where $\mathrm{ET}_{0}$ is reference evapotranspiration $\left(\mathrm{mm} \mathrm{day}^{-1}\right), \Delta$ is the slope of saturation vapour pressure-temperature curve $\left(\mathrm{kPa}{ }^{\circ} \mathrm{C}^{-1}\right), \gamma$ is the psychrometric constant $\left(\mathrm{kPa}^{\circ} \mathrm{C}^{-1}\right), R_{\mathrm{n}}$ is the net radiation ( $\mathrm{mm}$ (mbar)), $c$ is the adjustment factor, $f(U)$ is the wind function, $e_{\mathrm{s}}$ is the saturation vapour pressure (mbar), $e_{\mathrm{a}}$ is actual vapour pressure.

Consequently, the wind function was conducted following to Doorenbos and Pruitt (1977) as

$f(U)=0.27\left(1+\frac{U_{2}}{100}\right)$,

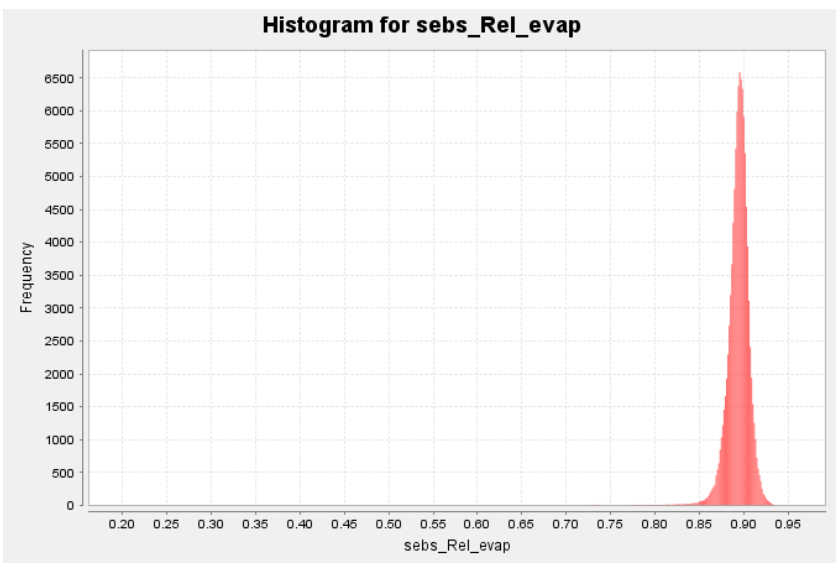

Figure 5. Normal distribution of relative evaporation data.

where $U_{2}$ is the wind-speed-measured surface at $2 \mathrm{~m}$ height $\left(\mathrm{km} \mathrm{day}^{-1}\right)$.

Meanwhile, $e_{\mathrm{a}}$ was calculated according to Allen et al. (1998) as follows:

$e_{\mathrm{a}}=\frac{e^{o}\left(T_{\min }\right)\left(\mathrm{RH}_{\max } / 100\right)+e^{o}\left(T_{\max }\right)\left(\mathrm{RH}_{\min } / 100\right)}{2}$,

where $e^{o}\left(T_{\min }\right)$ is the saturation vapour pressure at a daily minimum temperature $(\mathrm{kPa}), e^{o}\left(T_{\max }\right)$ is the saturation vapour pressure at a daily maximum temperature $(\mathrm{kPa})$, $\mathrm{RH}_{\text {max }}$ is the maximum relative humidity (\%), $\mathrm{RH}_{\min }$ is minimum relative humidity $(\%)$.

Linear regression model was used to find the correlation coefficient between the estimated and the actual evapotranspiration values. Root mean square error (RMSE) was used to signify the inequality of variance and correlation of the linear regression model (Box, 1954). The RMSE was calculated as follows:

$\mathrm{RMSE}=\left[N^{-1} \sum_{i=1}^{N}\left(P_{i}-O_{i}\right)^{2}\right]^{0.5}$ 


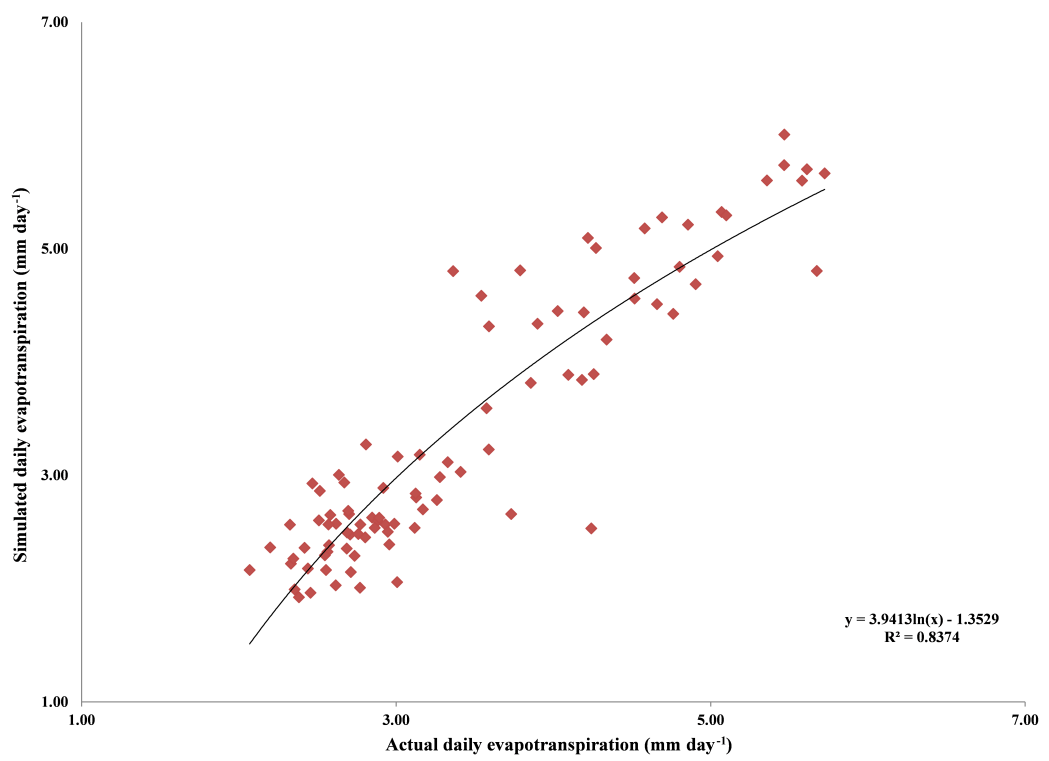

Figure 6. The relationship between actual and simulated daily evapotranspiration.

where $N$ is the number of observations, $P_{i}$ is the predicted ET values $\left(\mathrm{mm} \mathrm{day}^{-1}\right), O_{i}$ is the calculated ET values $\left(\mathrm{mm} \mathrm{day}^{-1}\right)$.

\section{Results and discussion}

The SEBS model implementation over the designated study area results in 10 different turbulent heat fluxes thematic maps. The histogram and the scatter plot of SEBS output thematic maps were plotted against the daily evapotranspiration values. The estimated daily evapotranspiration values ranged from zero to $6.61 \mathrm{~mm} \mathrm{day}^{-1}$. The spatial distribution of the highest evapotranspiration area is the peripheral of the agricultural pivots as demonstrated in Fig. 2. The circular movement of the pivots drives the excess irrigated water towards the prereferral of the irrigated fields leading to higher salinity levels (Zwart and Bastiaanssen, 2004; Cruz-Blanco et al., 2014). The mean actual evapotranspiration value is almost $5 \mathrm{~mm} \mathrm{day}^{-1}$ (Fig. 3), which is considered a high value for arid conditions (Elhag et al., 2011). Such an evapotranspiration value supports the hypothesis of the mismanagement of irrigational water in Wadi ad-Dawasir. Principally under extreme dry climate conditions, relative evaporation may reach unity (Lockwood, 1999). The relative evaporation thematic map, demonstrated in Fig. 4, confirms high correspondence between the actual and potential evapotranspiration, especially in the peripheral of the agricultural pivots. Normal distribution of the relative evaporation is demonstrated in Fig. 5. Mean relative evaporation ratio is counted for 0.91 . Only within the pivots, the relative evaporation decreases to 0.45 indicating the wet condition of the agricultural land (De Bruin et al., 2010). Fifty points of ground truthing data of daily evapotranspiration were collected during July 2013. The points were consistently distributed over the designated study area. Daily evapotranspiration estimation was conducted according to Liu and Wang (1999) using the Lysimeter with a calibrated accuracy of \pm 0.025 . The actual evapotranspiration data were intersected with the estimated raster image under a GIS environment. A linear regression model with an $R^{2}$ value of 0.83 was conducted to assess the association between the estimated and actual measured values (Fig. 6).

Implementation of the SEBS model over the designated study area showed higher daily evapotranspiration values than projected. Higher daily evapotranspiration values were noticed because the sensible heat flux is the major part of the energy, while the latent heat flux is dominating only over the agricultural area (Frey et al., 2011; Elhag, 2014a, b). The behaviour of the SEBS model could be explained by its tendency to simulate the potential daily evapotranspiration rather than the actual daily evapotranspiration, which is identified as the lack of leaf area index value over desert areas (Li et al., 2009; Elhag et al., 2011). The application of the SEBS model over the designated study area showed an insignificant difference to the Nile Delta case in term of accuracy assessment (Elhag et al., 2013).

\section{Conclusions}

Projected evapotranspiration data using a surface energy balance system model and multiple remote sensing imageries demonstrated robust association with the ground truth data. The application of the surface energy balance system model mapped the daily evapotranspiration and evaporative frac- 
tion objectively over Wadi ad-Dawasir region. The findings of the current research will help the decision makers towards a modification of the agriculture activities in similar areas in terms of conservative irrigational water regulations. The model shows consistent results in the estimation of daily evapotranspiration in Nile Delta region and in Wadi ad-Dawasir. Accordingly, the surface energy balance system model can be considered a reliable and effective tool in the estimation of daily evapotranspiration, explicitly in arid environments.

Competing interests. The authors declare that they have no conflict of interest.

Acknowledgements. This project was funded by the Deanship of Scientific Research (DSR) at King Abdulaziz University, Jeddah, under grant no. (G-182-155-37). The authors, therefore, acknowledge DSR technical and financial support with thanks.

Edited by: L. Eppelbaum

Reviewed by: N. Yilmaz and S. Boteva

\section{References}

Allen, R. G., Pereira, L. S., Raes, D., and Smith, M.: Crop evapotranspiration: guidelines for computing crop water requirements, in: FAO Irrigation and Drainage Paper No. 56, FAO, Rome, Italy, 300 pp., 1998.

Allen, R. G., Tasumi, M., and Trezza, R.: Satellite-based energy balance for mapping evapotranspiration with internalized calibration (METRIC) - Model, American Society of Civil Engineers, J. Irrig. Drain. E.-ASCE, 133, 380-394, 2007a.

Allen, R. G., Tasumi, M., Morse, A. T., Trezza, R., Kramber, W., Lorite, I., and Robison, C. W.: Satellite-based energy balance for mapping evapotranspiration with internalized calibration (METRIC) - Applications, American Society of Civil Engineers, J. Irrig. Drain. E.-ASCE, 133, 395-406, 2007b.

Al-Zahrani, K. H. and Baig, M. B.: Water in the Kingdom of Saudi Arabia: Sustainable Management Options, J. Anim. Plant Sci., 21, 601-604, 2011.

Bastiaanssen, W. G. M., Pelgrum, H., Wang, J., Ma, Y., Moreno, J., Roerink, G. J., and van der Wal, T.: The Surface Energy Balance Algorithm for Land (SEBAL): Part 2 validation, J. Hydrol., 212, 198-212, 2011.

Beljaars, A. C. M. and Holtslag, A. A. M.: Flux parameterization over land surfaces for atmospheric models, J. Appl. Meteorol., 30, 327-341, 1991.

Berengena, J. and Gavilán, P.: Reference evapotranspiration Estimation in a highly advective semiarid environment, American Society of Civil Engineers, J. Irrig. Drain. E.-ASCE, 131, 147163, 2005.

Box, G. E. P.: Some Theorems on Quadratic Forms Applied in the Study of Analysis of Variance Problems, II: Effects of Inequality of Variance and Correlation Between Errors in the Two-Way Classification, Ann. Math. Stat., 1, 69-82 1954.
Brest, C. L. and Goward, S. N.: Deriving Surface Albedo Measurements from Narrow Band Satellite Data, Int. J. Remote Sens., 8, 351-367 1987.

Brutsaert, W.: Evaporation into the atmosphere, Reidel, Dordrecht, 299 pp., 1982.

Brutsaert, W.: The formulation of evaporation from land surfaces, in: Recent Advances in the Modeling of Hydrologic Systems, edited by: Bowles, D. S. and O'Connell, P. E., 67-84, Kluwer Academic Publishers, Boston, MA, USA, 1991.

Brutsaert, W.: Aspects of Bulk Atmospheric Boundary Layer Similarity under Free Convective Conditions, Rev. Geophys., 37, 439-451, 1999.

Cammalleri, C. and Ciraolo, G.: A simple method to directly retrieve reference evapotranspiration from geostationary satellite images, Int. J. Appl. Earth Obs., 21, 149-158, 2013.

Chávez, J. L., Neale, C. M. U., Hipps, L. E., Prueger, J. H., and Kustas, W. P.: Comparing aircraft-based remotely sensed energy balance fluxes with eddy covariance tower data using heat flux source area functions, J. Hydrometeorol., 6, 923-940, 2005.

Crago, R. and Crowley, R.: Complementary relationship for near instantaneous evaporation, J. Hydrol., 300, 199-211, 2005.

Cristóbal, J. and Anderson, M. C.: Validation of a Meteosat Second Generation solar radiation dataset over the northeastern Iberian Peninsula, Hydrol. Earth Syst. Sci., 17, 163-175, doi:10.5194/hess-17-163-2013, 2013.

Cruz-Blanco, M., Gavilán, P., de Bruin, H. A. R., Trigo, I. F., Santos, C., and Lorite, I. J.: Reference evapotranspiration assessment using remote sensing and forecasting tools under semi-arid conditions, Int. J. Appl. Earth Obs., 33, 280-289, 2014.

de Bruin, H. A. R., Trigo, I. F., Jitan, M. A., Temesgen Enku, N., van der Tol, C., and Gieske, A. S. M.: Reference crop evapotranspiration derived from geo-stationary satellite imagery: a case study for the Fogera flood plain, NW-Ethiopia and the Jordan Valley, Jordan, Hydrol. Earth Syst. Sci., 14, 2219-2228, doi:10.5194/hess-14-2219-2010, 2010.

Elhag, M.: Evaluation of Different Soil Salinity Mapping Using Remote Sensing Techniques in Arid Ecosystems, Saudi Arabia, Journal of Sensors, 2016, 96175-96175, 2016.

Elhag, M.: Remotely Sensed Vegetation Indices and Spatial Decision Support System for Better Water consumption Regime in the Nile Delta. A Case Study for Rice Cultivation Suitability Map, Life Science Journal, 11, 201-209, 2014a.

Elhag, M.: Sensitivity Analysis Assessment of Remotely Based Vegetation Indices to Improve Water Resources Management, Environment Development and Sustainability, 16, 1209-1222, 2014b.

Elhag, M., Psilovikos, A., Manakos, I., and Perakis, K.: Application of the SEBS Water Balance Model in Estimating Daily Evapotranspiration and Evaporative Fraction from Remote Sensing Data over the Nile Delta, Water Resour. Manag., 25, 2731-2742, 2011.

Elhag, M., Psilovikos, A., and Sakellariou, M.: Detection of Land Cover Changes for Water Recourses Management Using Remote Sensing Data over the Nile Delta Region, Environment Development and Sustainability, 15, 1189-1204, 2013.

Espadafor, M., Lorite, I. J., Gavilán, P., and Berengena, J.: An analysis of the tendency of reference evapotranspiration estimates and other climate variables during the last 45 years in Southern Spain, Agr. Water Manage., 98, 1045-1061, 2011. 
Frey, C., Parlow, E., Vogt, R., Harhash, M., and Abel Wahab, M.: Flux measurements in Cairo. Part 1: in situ measurements and their applicability for comparison with satellite data, Int. J. Climatol., 31, 218-231, 2011.

Gavilán, P., Lorite, I. J., Tornero, S., and Berengena, J.: Regional calibration of Hargreaves equation for estimating reference ET in a semiarid environment, Agr. Water Manage., 81, 257-281, 2006.

Ghilain, N., Arboleda, A., and Gellens-Meulenberghs, F.: Evapotranspiration modelling at large scale using near-real time MSG SEVIRI derived data, Hydrol. Earth Syst. Sci., 15, 771-786, doi:10.5194/hess-15-771-2011, 2011.

Hanson, R. L.: Evapotranspiration and Drought, in: National Water Summary 1988-89 - Hydrologic Events Floods and Droughts, edited by: Paulson, R. W., Chase, E. B., Roberts, R. S., and Moody, D. W., USGS, Water-Supply paper 2375, 99-104, 1991.

Jensen, J., Rutchey, K., Koch, M., and Narumalani, S.: Inland wetland change detection in the everglades water conservation area 2A using a time series of normalized remotely sensed data, Photogramm. Eng. Rem. S., 51, 199-209, 1995.

Li, Z., Tang, R., Wan, Z., Bi, Y., Zhou, C., Tang, B., Yan, G., and Zhang, X.: A review of current methodologies for regional evapotranspiration estimation from remotely sensed data, Sensors, 9, 3801-3853, 2009.

Liu, C. and Wang, H.: The interface processes of water movement in the soil-crop-atmosphere system and water-saving regulation, Beijing Science Press, Beijing, 24-101, 1999.

Lockwood, J. G.: Is Potential Evapotranspiration and Its Relationship with Actual Evapotranspiration Sensitive to Elevated Atmospheric $\mathrm{CO}_{2}$ Levels?, Climatic Change, 41, 193-212, 1999.

Loheide, S. P. and Gorelick, S. M.: A local-scale, high-resolution evapotranspiration mapping algorithm (ETMA) with hydroecological applications at riparian meadow restoration sites, Remote Sens. Environ., 98, 182-200, 2005.

Monteith, J. L.: Evaporation and environment, Sym. Soc. Exp. Biol., 19, 205-234, 1965.
Monteith, J. L.: Evaporation and surface temperature, Q. J. Roy. Meteor. Soc., 107, 1-27, 1981.

Pruitt, W. and Doorenbos, J.: Empirical Calibration: A Requisite for Evapotranspiration Formulae Based on Daily Or Longer Mean Climate Data?, The Committee, 1977.

Psilovikos, A. and Elhag, M.: Forecasting of Remotely Sensed Daily Evapotranspiration Data over Nile Delta Region, Egypt, Water Resour. Manag., 27, 4115-4130, 2013.

Rahman, H. and Dedieu, G.: SMAC: a simplified method for the atmospheric correction of satellite measurements in the solar spectrum, Remote Sens., 15, 123-143, 1994.

Roerink, G. J., Su, Z., and Menenti, M.: A simple remote sensing algorithm to estimate the surface energy balance, Phys. Chem. Earth, 25, 147-157, 2000.

Su, Z.: A surface energy balance system (SEBS) for estimation of turbulent heat fluxes from point to continental scale, in: Advanced earth observation land surface climate, edited by: Su, Z. and Jacobs, C., Publications of the National Remote Sensing Board (BCRS), USP-2, 184-185, 2001.

$\mathrm{Su}, \mathrm{Z}$.: The Surface Energy Balance System (SEBS) for estimation of turbulent heat fluxes, Hydrol. Earth Syst. Sci., 6, 85-100, doi:10.5194/hess-6-85-2002, 2002.

Su, Z., Schmugge, T., Kustas, P., and Massman, J.: An evaluation of two models for estimation of the roughness height for heat transfer between the land surface and the atmosphere, J. Appl. Meteorol., 40, 1933-1951, 2001.

Taylor, A.: A method for surface irrigation design based on infiltration using the border strip as an infiltrometer, $\mathrm{PhD}$ thesis, University of Canterbury, Lincoln College, New Zealand, p. 228, 1981.

Van den Hurk, B. J. J. M. and Holtslag, A. A. M.: On the bulk parameterization of surface fluxes for various conditions and parameter ranges, Bound.-Lay. Meteorol., 82, 119-133, 1997.

Zwart, S. J. and Bastiaanssen, W. M. G.: Review of measured crop water productivity values for irrigated wheat, rice, cotton and maize, Agr. Water Manag., 69, 115-133, 2004. 